\title{
H5N1 Associated Human Fatality in Nepal- A First Case
}

\author{
Bhuvan Saud ${ }^{1 *}$ and Saroj Adhakari ${ }^{2}$ \\ ${ }^{1}$ Department of Medical Laboratory Technology, Jeanmarie Foundation Institute of Health Sciences (JFIHS), Nepal \\ ${ }^{2}$ Medical Laboratory Technologist, Government of Nepal, Nepal
}

*Corresponding author: Bhuvan Saud, Department of Medical Laboratory Technology, Janamaitri Foundation Institute of Health

Sciences (JFIHS), Nepal

\begin{tabular}{|c|c|}
\hline ARTICLE INFO & ABSTRACT \\
\hline Received: 㓞 July 16, 2019 & Citation: Bhuvan Saud, Saroj Adhakari. H5N1 Associated Human Fatality in Nepal- A First \\
\hline Published: 㓞 July 22, 2019 & Case. Biomed J Sci \& Tech Res 19(5)-2019. BJSTR. MS.ID.003366. \\
\hline
\end{tabular}

\section{Editorial}

Ministry of Health and Population has confirmed the first case of human causality by H5N1.21-year-old patient hospitalized due to fever and cough died on 29th March 2019. Molecular diagnosis was performed in National Public Health Laboratory, Nepal and for further confirmation sample was analyzed in Japan. According to World Health Organization, between 2003 and 2018, 860 human cases were reported and 454 conformed death from 16 different countries out of which higher death rate was reported from Indonesia and Egypt, 168 and 120 respectively [1]. Although, H5N1 usually does not infect human, high number of viruscontaining saliva, mucous and fecal material from infected bird may infect humans through air. The virus may enter into human through a person's eyes, nose or mouth. The clinical presentation of the disease can be mild to severe, which includes flu to multiorgan involvement and mortality rate is about $60 \%$ in human [2]. Poultry sector contributes to $3.5 \%$ GDP of Nepal and more than 70 thousand people are directly or indirectly employed in the sector

and they are in direct contact to poultry or their raw products. They are at higher risk of being infected [3]. Alongside, lack of managed slaughter houses, inadequate knowledge about handling, packaging and unhygienic and uncooked eating practices can subsequently added the risk on more than $90 \%$ Nepalese population [4]. It is very necessary to ensure the safety of poultry workers, ensure safe slaughterhouses and make the public aware of the consequences of unhygienic ways of handling or eating poultry products.

\section{References}

1. WHO/GIP (2013) Cumulative number of confirmed human cases for avian influenza $\mathrm{A}(\mathrm{H} 5 \mathrm{~N} 1)$.

2. CDC (2004) Highly Pathogenic Asian Avian Influenza A(H5N1) in people.

3. FAO (2014) Poultry sector Nepal. FAO animal production and health livestock country reviews. No. 8. Rome.

4. Saud B, Paudel G, Khichaju S, Bajracharya D, Dhungana G, et al. (2019) Multidrug-resistant bacteria from raw meat of buffalo and chicken, Nepal. Vet Med Int 2: 7960268.

\section{ISSN: 2574-1241}

DOI: $10.26717 /$ BJSTR.2019.19.003366

Bhuvan Saud. Biomed J Sci \& Tech Res

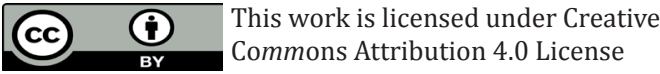

Submission Link: https://biomedres.us/submit-manuscript.php

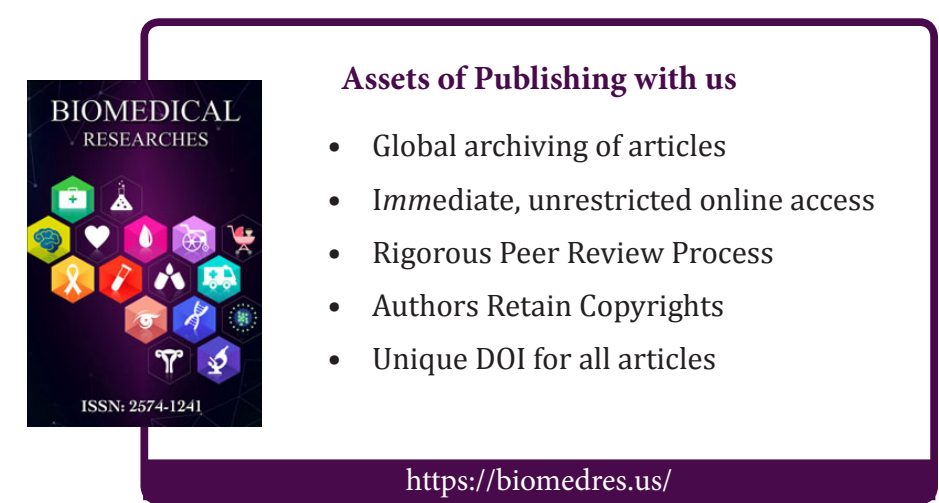

